\title{
マイクロポーラ弾性体理論を用いた連続体表現に基づく格子構造の最適設計
}

\author{
佐藤 綾美*1, 山田 崇恭*1 ${ }^{* 1}$ 泉井 一浩*1，西脇 眞二*2，寺田 賢二郎 ${ }^{* 3}$
}

\section{Optimum design of lattice structures based on continuum expression using micropolar continuum theory}

\author{
Ayami SATO $^{* 1}$, Takayuki YAMADA ${ }^{* 1}$, Kazuhiro IZUI ${ }^{* 1}$, Shinji NISHIWAKI ${ }^{* 2}$ \\ and Kenjiro TERADA ${ }^{* 3}$ \\ ${ }^{*} 1,{ }^{*}$ Department of Mechanical Engineering and Science, Kyoto University \\ Kyotodaigaku-katsura CIII, Nishikyo-ku, Kyoto 615-8540, Japan \\ ${ }^{*}$ International Research Institute of Disaster Sciense, Tohoku University \\ 468-1 Aramaki Aza-Aoba, Aoba-ku, Sendai-shi, Miyagi 980-0845, Japan
}

\section{Received 14 April 2016}

\begin{abstract}
We construct a structural optimization method targeting lattice structures composed of a sufficiently large array of unit cells where each unit cell consists of several beam elements, with the aim of maximizing the stiffness of the entire structure under a volume constraint. In this method, micropolar continuum theory is introduced for continuum modeling of the lattice structures because micropolar continua and beam elements both have rotational degrees of freedom in addition to translational degrees of freedom. That is, the material behavior of a micropolar continuum that is equivalent to the lattice structure is obtained so that the strain energy density of the micropolar continuum is equal to the volume average of the strain energy stored in a unit cell of the lattice structure, which is derived from the framework of classical beam theory. The conventional finite element method is expanded for numerical analyses of the micropolar continuum to take the rotational degrees of freedom into account. The optimization algorithm has the width of each frame element set as a design variable and represented as a continuous distribution in the modeling of the micropolar continuum. Finally, two design examples are provided to confirm the validity and effectiveness of the proposed method.
\end{abstract}

Key words : Optimum design, Material design, Finite element method, Lattice structure, Micropolar continuum theory

1. 緒言

骨組み要素で構成される格子構造は，軽量でありながら高剛性という特性を持ち，航空分野や生体医療分野な ど幅広い分野で活用されている (Vasiliev and Razin, 2006; Lantada and Morgado, 2012). 近年では製造技術の向上に より，設計した格子構造を低いコストで精度良く作成することが可能となっており，さらに注目が集まっている (Yan et al., 2006).

格子構造の設計手法は，その格子構造により形成される巨視的な構造，つまりマクロ構造について，周期的な 応答を仮定しマクロ構造そのものの物理的状態については考慮しないか, あるいはマクロ構造そのもののある特 定の物理的状態を考慮するかによって，大きく二つに分類することができる.

まず，マクロ構造の物理的状態を考慮しない場合においては，格子構造内の周期的なミクロ構造単位，いわゆる

No.16-00171 [DOI:10.1299/transjsme.16-00171], J-STAGE Advance Publication date : 22 July, 2016

${ }_{* 1}$ 正員, 京都大学大学院工学研究科 (

*2 正員, フェロー, 京都大学大学院工学研究科

*3 正員, フェロー，東北大学㷋害科学国際研究所（干980-0845 宮城県仙台市青葉区荒巻字青葉 468-1）

E-mail of corresponding author: satou.ayami.34u@st.kyoto-u.ac.jp 
ユニットセルから算出される巨視的な材料特性を設計評価値とし, ユニットセル内の要素の断面積等の諸元を設 計する (Elsayed and Pasini, 2010; Ju and Summers, 2011). この手法ではユニットセルから構成されるマクロ構造の 物理的状態については考慮せずユニットセルのみの設計を行うため評価する際の計算コストを削減できるが， マ クロ構造全体の性能評価との関連付けは難しいという面を持つ.

一方，マクロ構造の物理的状態を考慮する場合においては，格子構造の設計をマクロ構造の力学的な応答に基 づいて行うため, 抜本的な性能改善が期待できる. しかしながら, この場合にはマクロ構造全体に対する数值解 析が必要不可欠である. このとき, 格子構造そのものを数值モデルとして数值解析を行うと, 正確な応力分布や ひずみ分布を得ることができるものの, 計算量が膨大になってしまい, 設計問題として取り扱うことは現実的で はない，その解決策として，マクロ構造全体を等価な連続体として表現することにより数值解析の計算コストの 削減を図るという手法が知られている(Onck, 2002).

トラス要素によって構成された格子構造は, 並進の三自由度を持つ古典弾性体モデルを用いた数值解析により 精度よく変形を表現することができるが, 並進の三自由度に加えて回転の三自由度を持つフレーム要素によって 構成された格子構造に対しては, 古典弾性体モデルでは変形を正確に表現することができない (Noor and Nemeth, 1980a, 1980b). しかしながら, 自動車や航空機のような機械構造に用いられる格子構造は, 格子内部でのモーメ ントの伝達が極めて重要であるため, 設計段階でフレーム要素を用いる必要がある (西脇他, 2001)。このようなフ レーム要素で構成された格子構造を連続体として表現するために, マイクロポーラ弾性体モデルの適用が考えら れる.

マイクロポーラ弾性体理論 (Eringen, 1966) では，物質点に対して並進の自由度に加えて，並進変位とは独立に 定義される回転の自由度, すなわちマイクロ回転が導入される. また, マイクロポーラ弾性体理論において隣り 合う物質点の相互作用は, 応力のみならず偶応力を介しても行われる. この理論においては, ミクロ構造の特徵 長さがマクロ構造の材料パラメータに反映されることが知られている (Adachi et al., 1998).

フレーム要素と同様に, 並進とともに回転の自由度を持つマイクロポーラ弾性体は, フレーム要素で構成され た格子構造の数值モデルとして適していると考えられており, 多くの理論的考察が行われているほか実験的にも 妥当性が検証されている (Bažant and Christensen, 1972; Onck, 2002; Kumar and McDowell, 2004). しかし, 最適設 計への展開はいまだ格子のスケールや密度の最適化に限定されており (Yan et al., 2008), 格子内部の構造まで扱う ことが可能な手法は提案されていない.

そこで, 本研究では, フレーム要素で構成された格子構造をマイクロポーラ弾性体に基づく数值モデルとして 表現し, マクロ構造の物理的状態を反映した格子内部の新しい構造最適化手法を提案する. すなわち, 目的関数 としてマクロ構造の力学的応答を設定し, マイクロポーラ弾性体として表現されたマクロ構造の数值解析結果を もとに格子構造内部の最適化を行う. 具体的には, 格子構造を構成する梁の幅を設計変数として, マクロ構造の 力学的な応答を改善する巨視的な梁の幅の最適分布を求める手法を構築する.

以下， 2 章ではマイクロポーラ弾性体理論について概説する. 3 章では, 梁要素で構成された格子構造をマイ クロポーラ弾性体に近似する手法について述べる，4章では，最適化問題の定式化を行い，それに基づき最適化 アルゴリズムを構築する．5章では，数值例により本提案手法の妥当性について検証する.

\section{2. マイクロポーラ弾性体理論}

古典弾性体理論では, 連続体の各物質点は変位の自由度を持ち, 応力に関する平衡方程式が成り立つ. マイクロ ポーラ弾性体理論はこの古典弾性体理論をより一般的に拡張したものであり, 連続体の各物質点が変位 $u_{i} に$ 加え てマイクロ回転 $\phi_{i}$ という回転の自由度をもつ. この回転の自由度は, 剛体回転とは異なり変位の自由度とは独立 に定義されるものである. また，応力 $\sigma_{i j}$ だけでなく偶応力 $\tau_{i j}$ に関する平衡方程式も成立する. マイクロポーラ 弾性体のひずみテンソル $\varepsilon_{i j}$ は, 古典弾性体のひずみテンソルとは異なり非対称性を持ち, 以下のように表される.

$$
\varepsilon_{i j}=u_{j, i}-e_{i j k} \phi_{k}
$$

ここで， $e_{i j k}$ は三階の交代テンソルを表す.一方, 曲率テンソル $\chi_{i j}$ は次式のように表される.

$$
\chi_{i j}=\phi_{j, i}
$$


構成式は, ひずみについての弾性テンソルを $C_{i j k l}$, 曲率についての弾性テンソルを $K_{i j k l}$, 連成項についての弾性 テンソルを $B_{i j k l}$ とすると,

$$
\begin{aligned}
\sigma_{i j} & =C_{i j k l} \varepsilon_{k l}+B_{i j k l} \chi_{k l} \\
\tau_{i j} & =B_{k l i j} \varepsilon_{k l}+K_{i j k l} \chi_{k l}
\end{aligned}
$$

となる.このとき，平衡方程式は，

$$
\begin{aligned}
& \sigma_{j i, j}+f_{i}=0 \\
& \tau_{j i, j}+e_{i k l} \sigma_{k l}+b_{i}=0
\end{aligned}
$$

となる．ここで， $f_{i}$ は体積力， $b_{i}$ は体積偶力を表す．変位とマイクロ回転のディリクレ境界条件はそれぞれ以下 のようになる.

$$
\begin{aligned}
u_{i} & =\bar{u}_{i} \\
\phi_{i} & =\bar{\phi}_{i}
\end{aligned}
$$

またノイマン境界条件は,

$$
\begin{aligned}
\sigma_{j i} n_{j} & =\bar{t}_{i} \\
\tau_{j i} n_{j} & =\bar{m}_{i}
\end{aligned}
$$

となる.ここで， $\bar{u}_{i} ， \bar{\phi}_{i}$ はそれぞれ規定された変位とマイクロ回転の值， $\bar{t}_{i} ， \bar{m}_{i}$ はそれぞれ規定された表面力と表 面偶力の值を示しており， $n_{j}$ は境界の外向き単位法線ベクトルである.

本研究では二次元のマイクロポーラ弾性体を対象とするため, 各物質点は変位 $u_{1}, u_{2}$, 及びマイクロ回転 $\phi\left(=\phi_{3}\right)$ の自由度を持つ.このとき，ひずみエネルギー密度 $w$ は以下のように表される.

$$
w=w\left(\varepsilon_{11}, \varepsilon_{22}, \varepsilon_{12}, \varepsilon_{21}, \chi_{13}, \chi_{23}\right)
$$

このとき, 応力テンソルと偶応力テンソルの各成分は, ひずみエネルギー密度をひずみテンソル及び曲率テンソ ルの各成分で微分することにより得られる。

$$
\begin{aligned}
& \sigma_{11}=\frac{\partial w}{\partial \varepsilon_{11}}=\frac{\partial w}{\partial u_{1,1}} \\
& \sigma_{22}=\frac{\partial w}{\partial \varepsilon_{22}}=\frac{\partial w}{\partial u_{2,2}} \\
& \sigma_{12}=\frac{\partial w}{\partial \varepsilon_{12}}=\frac{\partial w}{\partial\left(u_{2,1}-\phi\right)} \\
& \sigma_{21}=\frac{\partial w}{\partial \varepsilon_{21}}=\frac{\partial w}{\partial\left(u_{1,2}+\phi\right)} \\
& \tau_{13}=\frac{\partial w}{\partial \chi_{13}}=\frac{\partial w}{\partial \phi_{, 1}} \\
& \tau_{23}=\frac{\partial w}{\partial \chi_{23}}=\frac{\partial w}{\partial \phi_{, 2}}
\end{aligned}
$$

\section{3. 格子構造の連続体近似}

本研究では, Kumar and McDowell の方法に基づき, 図 1 の格子構造をマイクロポーラ弾性体としてモデル化す る (Kumar and McDowell, 2004). すなわち，図 1 中の破線で囲まれた部分をユニットセルとし，ユニットセル内の 各方向に軸をとる梁の幅を $h^{(\alpha)}(\alpha=1,2,3,4)$ として, ユニットセル内のひずみエネルギー密度を求め, それをひ ずみテンソル及び曲率テンソルの各成分で微分することによって，マイクロポーラ弾性体としての弾性係数を求 める.

まず，図 2 に示すような隣り合う二節点 $\mathrm{I}, \mathrm{J}$ 間の梁について考える. 節点 $\mathrm{I}$ の変位を $\boldsymbol{u}^{I}$, 回転量を $\phi^{I}$, 節点 $\mathrm{J}$ の変位を $\boldsymbol{u}^{J}$, 回転量を $\phi^{J}$ とおき, これらを用いてこの梁に蓄えられるひずみエネルギー $W_{\mathrm{IJ}}$ を求める. 梁の長さ 


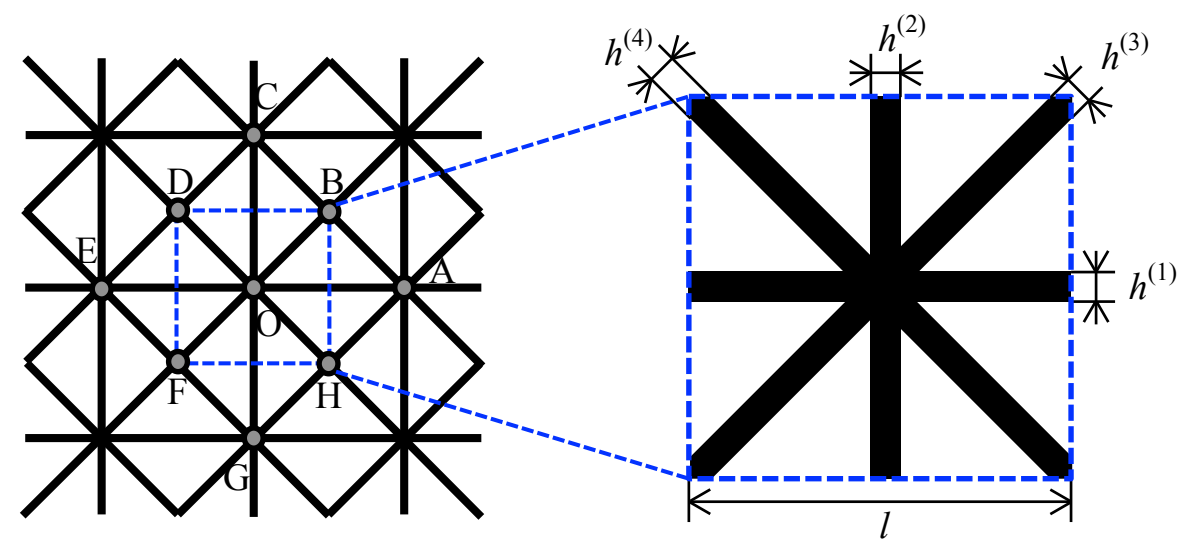

Fig. 1 Schematic of microstructure.

を $l_{b}$, 幅を $h$ とし，奥行きを 1 とすると， $W_{\mathrm{IJ}}$ は以下の式で表される.

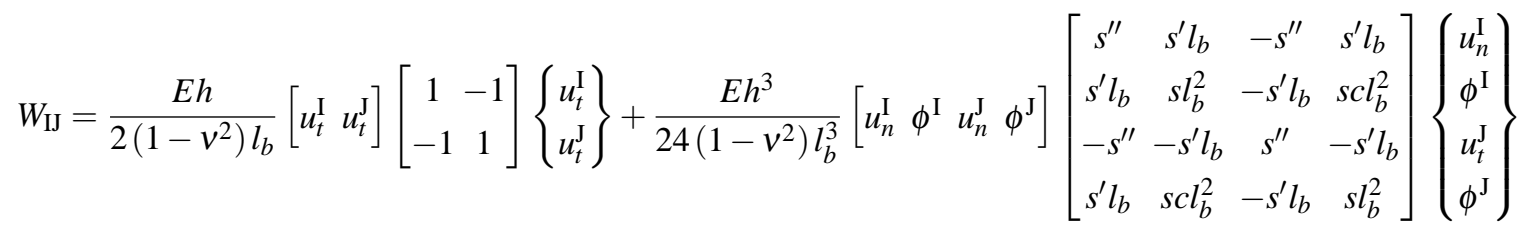

ここで，梁についてベルヌーイ・オイラー梁を仮定すると， $s=4, c=0.5, s^{\prime}=s(1+c), s^{\prime \prime}=2 s^{\prime}$ となる. また， $u_{t}, u_{n}$ はそれぞれ軸方向の変位と軸に直交する方向の変位を表している. 式（18）においてひずみエネルギーは,

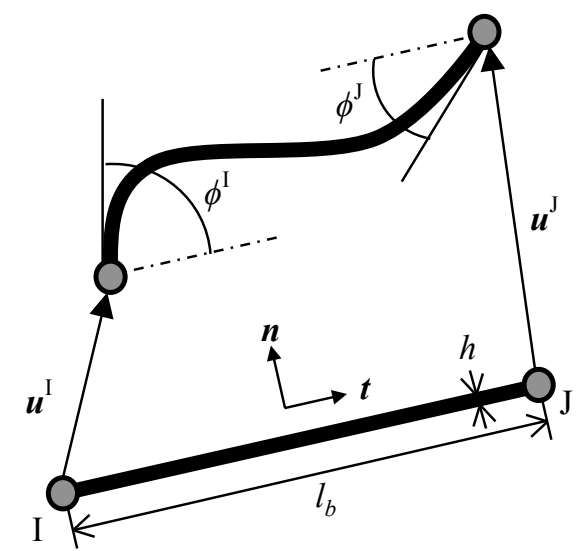

Fig. 2 Diagram of a deformed beam between node I and J.

節点の変位と回転量で表現されている.これらについて一次のテイラー展開を行うと以下のようになる.

$$
\begin{aligned}
& \boldsymbol{u}^{\mathrm{I}}=\boldsymbol{u}+L_{\mathrm{OI}} \frac{\partial \boldsymbol{u}}{\partial \boldsymbol{t}_{\mathrm{OI}}} \\
& \phi^{\mathrm{I}}=\phi+L_{\mathrm{OI}} \frac{\partial \phi}{\partial \boldsymbol{t}_{\mathrm{OI}}} \\
& \boldsymbol{u}^{\mathrm{J}}=\boldsymbol{u}+L_{\mathrm{OJ}} \frac{\partial \boldsymbol{u}}{\partial \boldsymbol{t}_{\mathrm{OJ}}} \\
& \phi^{\mathrm{J}}=\phi+L_{\mathrm{OJ}} \frac{\partial \phi}{\partial \boldsymbol{t}_{\mathrm{OJ}}}
\end{aligned}
$$

ここで， $\boldsymbol{u}, \boldsymbol{\phi}$ は原点 $\mathrm{O}$ での変位とマイクロ回転を表しており， $L_{\mathrm{OI}}, L_{\mathrm{OJ}}$ は原点 $\mathrm{O}$ から節点 $\mathrm{I}, \mathrm{J}$ までの距離, $\boldsymbol{t}_{\mathrm{OI}}$, $t_{\mathrm{OJ}}$ はそれぞれの単位方向ベクトルである。この近似された節点の変位と回転量を，それぞれマイクロポーラ弾性 
体の変位とマイクロ回転とみなし, 式（19）から式（22）を式（18）に代入することで, マイクロポーラ弾性体 としてのひずみエネルギーを得る.

次に図 1 のユニットセルについて考える. 原点 $\mathrm{O}$ をユニットセル中心に設定したため, ユニットセル中心の節 点の変位と回転が, マクロ構造のマイクロポーラ弾性体の変位 $\boldsymbol{u}$ とマイクロ回転 $\phi$ としてみなされる. ユニット セルのひずみエネルギー密度 $w$ を導出すると,

$$
w=\frac{1}{l^{2}}\left[\frac{1}{2}\left(W_{\mathrm{OA}}+W_{\mathrm{OC}}+W_{\mathrm{OE}}+W_{\mathrm{OG}}\right)+W_{\mathrm{OB}}+W_{\mathrm{OD}}+W_{\mathrm{OF}}+W_{\mathrm{OH}}\right]
$$

となる. 式（12）から式（17）に従って応力テンソルと偶応力テンソルの各成分を求めると以下のようになる.

$$
\begin{aligned}
& \sigma_{11}=\frac{1}{2}\left\{\left[2 E_{1}^{\prime}+\frac{1}{2}\left(E_{3}^{\prime}+E_{4}^{\prime}\right)+12\left(k_{3}^{\prime}+k_{4}^{\prime}\right)\right] \varepsilon_{11}+\left[\frac{1}{2}\left(E_{3}^{\prime}+E_{4}^{\prime}\right)-12\left(k_{3}^{\prime}+k_{4}^{\prime}\right)\right] \varepsilon_{22}\right. \\
& \left.+\left[\frac{1}{2}\left(E_{3}^{\prime}-E_{4}^{\prime}\right)-12\left(k_{3}^{\prime}-k_{4}^{\prime}\right)\right] \varepsilon_{12}+\left[\frac{1}{2}\left(E_{3}^{\prime}-E_{4}^{\prime}\right)+12\left(k_{3}^{\prime}-k_{4}^{\prime}\right)\right] \varepsilon_{21}\right\} \\
& \sigma_{22}=\frac{1}{2}\left\{\left[\frac{1}{2}\left(E_{3}^{\prime}+E_{4}^{\prime}\right)-12\left(k_{3}^{\prime}+k_{4}^{\prime}\right)\right] \varepsilon_{11}+\left[2 E_{2}^{\prime}+\frac{1}{2}\left(E_{3}^{\prime}+E_{4}^{\prime}\right)+12\left(k_{3}^{\prime}+k_{4}^{\prime}\right)\right] \varepsilon_{22}\right. \\
& \left.+\left[\frac{1}{2}\left(E_{3}^{\prime}-E_{4}^{\prime}\right)+12\left(k_{3}^{\prime}-k_{4}^{\prime}\right)\right] \varepsilon_{12}+\left[\frac{1}{2}\left(E_{3}^{\prime}-E_{4}^{\prime}\right)-12\left(k_{3}^{\prime}-k_{4}^{\prime}\right)\right] \varepsilon_{21}\right\} \\
& \sigma_{12}=\frac{1}{2}\left\{\left[\frac{1}{2}\left(E_{3}^{\prime}-E_{4}^{\prime}\right)-12\left(k_{3}^{\prime}-k_{4}^{\prime}\right)\right] \varepsilon_{11}+\left[\frac{1}{2}\left(E_{3}^{\prime}-E_{4}^{\prime}\right)+12\left(k_{3}^{\prime}-k_{4}^{\prime}\right)\right] \varepsilon_{22}\right. \\
& \left.+\left[\frac{1}{2}\left(E_{3}^{\prime}+E_{4}^{\prime}\right)+12\left(2 k_{1}^{\prime}+k_{3}^{\prime}+k_{4}^{\prime}\right)\right] \varepsilon_{12}+\left[\frac{1}{2}\left(E_{3}^{\prime}+E_{4}^{\prime}\right)-12\left(k_{3}^{\prime}+k_{4}^{\prime}\right)\right] \varepsilon_{21}\right\} \\
& \sigma_{21}=\frac{1}{2}\left\{\left[\frac{1}{2}\left(E_{3}^{\prime}-E_{4}^{\prime}\right)+12\left(k_{3}^{\prime}-k_{4}^{\prime}\right)\right] \varepsilon_{11}+\left[\frac{1}{2}\left(E_{3}^{\prime}-E_{4}^{\prime}\right)-12\left(k_{3}^{\prime}-k_{4}^{\prime}\right)\right] \varepsilon_{22}\right. \\
& \left.+\left[\frac{1}{2}\left(E_{3}^{\prime}+E_{4}^{\prime}\right)-12\left(k_{3}^{\prime}+k_{4}^{\prime}\right)\right] \varepsilon_{12}+\left[\frac{1}{2}\left(E_{3}^{\prime}+E_{4}^{\prime}\right)+12\left(2 k_{2}^{\prime}+k_{3}^{\prime}+k_{4}^{\prime}\right)\right] \varepsilon_{21}\right\} \\
& \tau_{13}=2\left(2 k_{1}^{\prime}+k_{3}^{\prime}+k_{4}^{\prime}\right) l^{2} \chi_{13}+2\left(k_{3}^{\prime}-k_{4}^{\prime}\right) l^{2} \chi_{23} \\
& \tau_{13}=2\left(k_{3}^{\prime}-k_{4}^{\prime}\right) l^{2} \chi_{13}+2\left(2 k_{2}^{\prime}+k_{3}^{\prime}+k_{4}^{\prime}\right) l^{2} \chi_{23}
\end{aligned}
$$

ここで, $E_{\alpha}^{\prime}=E h^{(\alpha)} /(1-v) l, k_{\alpha}^{\prime}=E\left(h^{(\alpha)}\right)^{3} / 12(1-v) l^{3}(\alpha=1,2,3,4)$ である. これらの式から, 以下に示すよ うにマイクロポーラ弾性体としての弾性係数を導出することができる.

$$
\begin{aligned}
& C_{1111}=\frac{1}{2}\left[2 E_{1}^{\prime}+\frac{1}{2}\left(E_{3}^{\prime}+E_{4}^{\prime}\right)+12\left(k_{3}^{\prime}+k_{4}^{\prime}\right)\right] \\
& C_{1122}=\frac{1}{2}\left[\frac{1}{2}\left(E_{3}^{\prime}+E_{4}^{\prime}\right)-12\left(k_{3}^{\prime}+k_{4}^{\prime}\right)\right] \\
& C_{1112}=\frac{1}{2}\left[\frac{1}{2}\left(E_{3}^{\prime}-E_{4}^{\prime}\right)-12\left(k_{3}^{\prime}-k_{4}^{\prime}\right)\right] \\
& C_{1121}=\frac{1}{2}\left[\frac{1}{2}\left(E_{3}^{\prime}-E_{4}^{\prime}\right)+12\left(k_{3}^{\prime}-k_{4}^{\prime}\right)\right] \\
& C_{2222}=\frac{1}{2}\left[2 E_{2}^{\prime}+\frac{1}{2}\left(E_{3}^{\prime}+E_{4}^{\prime}\right)+12\left(k_{3}^{\prime}+k_{4}^{\prime}\right)\right] \\
& C_{2212}=\frac{1}{2}\left[\frac{1}{2}\left(E_{3}^{\prime}-E_{4}^{\prime}\right)+12\left(k_{3}^{\prime}-k_{4}^{\prime}\right)\right] \\
& C_{2221}=\frac{1}{2}\left[\frac{1}{2}\left(E_{3}^{\prime}-E_{4}^{\prime}\right)-12\left(k_{3}^{\prime}-k_{4}^{\prime}\right)\right] \\
& C_{1212}=\frac{1}{2}\left[\frac{1}{2}\left(E_{3}^{\prime}+E_{4}^{\prime}\right)+12\left(2 k_{1}^{\prime}+k_{3}^{\prime}+k_{4}^{\prime}\right)\right] \\
& C_{1221}=\frac{1}{2}\left[\frac{1}{2}\left(E_{3}^{\prime}+E_{4}^{\prime}\right)-12\left(k_{3}^{\prime}+k_{4}^{\prime}\right)\right]
\end{aligned}
$$




$$
\begin{aligned}
C_{2121} & =\frac{1}{2}\left[\frac{1}{2}\left(E_{3}^{\prime}+E_{4}^{\prime}\right)+12\left(2 k_{2}^{\prime}+k_{3}^{\prime}+k_{4}^{\prime}\right)\right] \\
K_{1313} & =2\left(2 k_{1}^{\prime}+k_{3}^{\prime}+k_{4}^{\prime}\right) l^{2} \\
K_{1323} & =2\left(k_{3}^{\prime}-k_{4}^{\prime}\right) l^{2} \\
K_{2323} & =2\left(2 k_{2}^{\prime}+k_{3}^{\prime}+k_{4}^{\prime}\right) l^{2}
\end{aligned}
$$

ここで, 式（24）から式（29）より連成項についての弾性テンソルは $B_{i j k l}=0$ である. なお $C_{i j k l}=C_{k l i j}, K_{i 3 j 3}=K_{j 3 i 3}$ の対称性より, 独立な 13 成分のみを記載する.

\section{4. 最 適 設 計 法}

\section{$4 \cdot 1$ 最適化問題の定式化}

図 3 に示すマクロスケールにおける設計領域 $\Omega$ に, 図 1 に示すユニットセルが周期的に分布していると仮定す る. ユニットセル内の各方向に軸をとる梁の幅 $h^{(\alpha)}(\alpha=1,2,3,4)$ を設計変数とし, 3 章の手法を用いて, マイク ロポーラ弾性体としてのモデル化を行う。そのマイクロポーラ弾性体としてみなされる格子構造に対して体積の 上限值 $V_{\max }$ が規定されたとき, マクロ構造の剛性を最大化するような梁の幅 $h^{(\alpha)}$ の巨視的な分布を求めるという 問題を設定する。

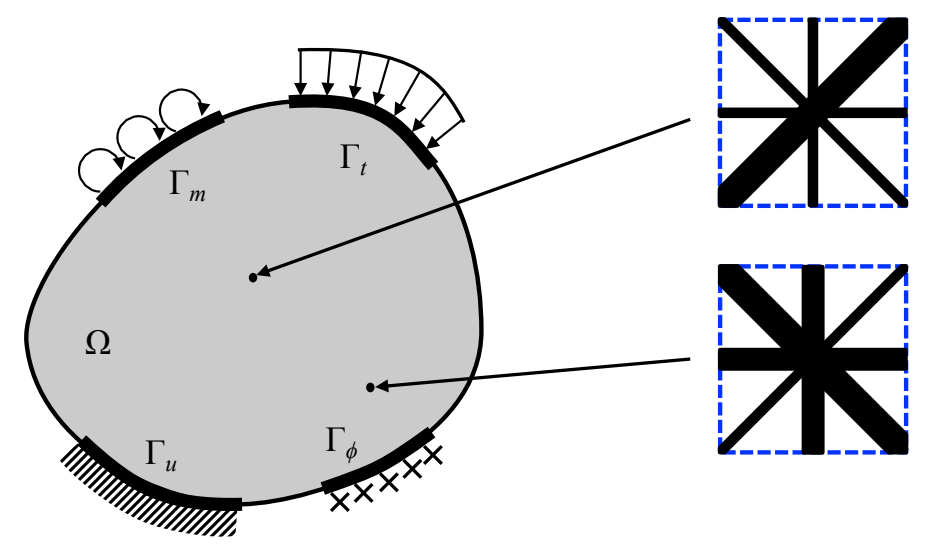

Fig. 3 Macrostructure considered as micropolar elastic solid and actual microstructure at each point.

図 3 に示したように，境界 $\Gamma_{u}, \Gamma_{\phi}$ において変位と回転がそれぞれ固定され，境界 $\Gamma_{t}$ に表面力 $\bar{t}_{i}$, 境界 $\Gamma_{m}$ に表 面偶力 $\bar{m}_{i}$ が作用しているとする. 簡単のため, 体積力と体積偶力はないものとすると, 平衡方程式は以下の弱形 式で表される.

$\int_{\Omega}\left[\left(\delta u_{j, i}-e_{i j 3} \delta \phi\right) C_{i j k l}\left(u_{l, k}-e_{k l 3} \phi\right)+\delta \phi_{, i} K_{i 3 k 3} \phi_{, k}\right] d V=\int_{\Gamma_{t}} \bar{t}_{i} \delta u_{i} d S+\int_{\Gamma_{m}} \bar{m}_{i} \delta \phi_{i} d S \quad$ for $\quad u_{i},{ }^{\forall} \delta u_{i} \in U \quad \phi,{ }^{\forall} \delta \phi \in P$

ここで, $\delta u_{i}, \delta \phi$ は仮想変位及び仮想マイクロ回転である. また, $U$ と $P$ は以下の運動学的可容変位場である.

$U=\left\{\delta u_{i} \quad\right.$ with $\delta u_{i}=0$ on $\left.\Gamma_{u}\right\}$

$P=\left\{\delta \phi \quad\right.$ with $\delta \phi=0$ on $\left.\Gamma_{\phi}\right\}$

また, ユニットセル内の体積分率を正規化された密度 $\rho$ とし, 以下のように表す.

$$
\rho=\frac{1}{l}\left(h^{(1)}+h^{(2)}+\sqrt{2} h^{(3)}+\sqrt{2} h^{(4)}\right)
$$


剛性最大化は，平均コンプライアンスの最小化により行う. 以上より，最適化問題は次のように定式化される.

$$
\begin{array}{ll}
\inf _{h^{(\alpha)}} & f=\int_{\Gamma_{t}} \bar{t}_{i} u_{i} d S+\int_{\Gamma_{m}} \bar{m}_{i} \phi_{i} d S \\
\text { subject to: } & \int_{\Omega}\left[\left(\delta u_{j, i}-e_{i j 3} \delta \phi\right) C_{i j k l}\left(u_{l, k}-e_{k l 3} \phi\right)+\delta \phi_{, i} K_{i 3 k 3} \phi_{, k}\right] d V=\int_{\Gamma_{t}} \bar{t}_{i} \delta u_{i} d S+\int_{\Gamma_{m}} \bar{m}_{i} \delta \phi_{i} d S \\
& g=\int_{\Omega} \rho d V-V_{\max } \leq 0 \\
& h_{\min } \leq h^{(\alpha)} \leq h_{\max } \quad \text { for } \quad \alpha=1,2,3,4
\end{array}
$$

\section{$4 \cdot 2$ 最適化アルゴリズム}

図 4 に本手法における最適化計算のフローチャートを示す．まず，初期の設計変数，すなわち各点での梁の幅 を与える. 次に, マイクロポーラ弾性体としてのモデル化を行ったのち, 有限要素法を用いて支配方程式を解き, 目的関数を算出する.ここで目的関数が収束していれば，最適化計算を終了する. 収束していなければ設計感度 を算出し, MMA (The Method of Moving Asymptotes) (Svanberg, 1987) を用いて各設計変数を更新して, マイクロ ポーラ弾性体としてのモデル化の手続きに戻る. 以上の手続きを, 目的関数が収束するまで繰り返し行い, 最適 解を得る.

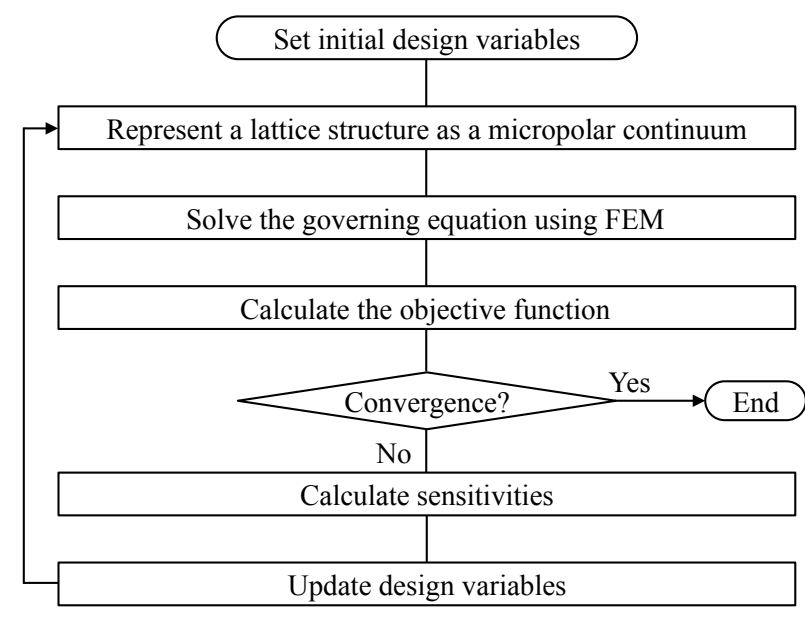

Fig. 4 Flowchart of the proposed optimization algorithm.

\section{$4 \cdot 3$ 数值実装法}

ここでは，有限要素法を用いた本手法の数值実装法について概説する．まず，構成式（3），(4）をまとめて行列 形式で表す.

$$
\boldsymbol{\sigma}=D \boldsymbol{\varepsilon}
$$

ここで， $\boldsymbol{\sigma}, \boldsymbol{\varepsilon}$ はそれぞれ以下のベクトルである.

$$
\begin{aligned}
\boldsymbol{\sigma} & =\left[\begin{array}{llllll}
\sigma_{11} & \sigma_{22} & \sigma_{12} & \sigma_{21} & \tau_{13} & \tau_{23}
\end{array}\right]^{T} \\
\boldsymbol{\varepsilon} & =\left[\begin{array}{llllll}
\varepsilon_{11} & \varepsilon_{22} & \varepsilon_{12} & \varepsilon_{21} & \chi_{13} & \chi_{23}
\end{array}\right]^{T}
\end{aligned}
$$

また, $D$ は $6 \times 6$ の行列で, 以下のように表される.

$$
D=\left[\begin{array}{rrrrr}
C_{1111} C_{1122} & C_{1112} & C_{1121} & 0 & 0 \\
C_{2222} & C_{2212} & C_{2221} & 0 & 0 \\
& C_{1212} & C_{1221} & 0 & 0 \\
& C_{2121} & 0 & 0 \\
\text { sym. } & & K_{1313} & K_{1323} \\
& & & K_{2323}
\end{array}\right]
$$


続いて, マイクロ回転を含む一般化変位ベクトル $\boldsymbol{v}$ は, 同様にマイクロ回転を含む一般化要素節点変位ベクト ル $\boldsymbol{d}_{e}$ と形状関数行列 $N$ により,

$$
\boldsymbol{v}=N \boldsymbol{d}_{e}
$$

と表される.したがって，式（38）のベクトル $\boldsymbol{\varepsilon}$ は,

$$
\boldsymbol{\varepsilon}=L \boldsymbol{v}=L N \boldsymbol{d}_{e}
$$

となる．ここで， $L$ は式 $(1) ，(2)$ の演算を表す行列であり，以下のように表される.

$$
L=\left[\begin{array}{ccc}
\frac{\partial}{\partial x_{1}} & 0 & 0 \\
0 & \frac{\partial}{\partial x_{2}} & 0 \\
0 & \frac{\partial}{\partial x_{1}} & -1 \\
\frac{\partial}{\partial x_{2}} & 0 & 1 \\
0 & 0 & \frac{\partial}{\partial x_{1}} \\
0 & 0 & \frac{\partial}{\partial x_{2}}
\end{array}\right]
$$

以上を用いて有限要素法の手続きに従うと，全体系の剛性方程式が以下のように求められる.

$$
K \boldsymbol{d}=\boldsymbol{F}
$$

ここで， $K$ は全体剛性マトリクス， $\boldsymbol{d}$ は一般化節点変位ベクトル， $\boldsymbol{F}$ は一般化節点力ベクトルである．なお離散化 の際には, 有限要素解析の要素サイズがユニットセルのサイズを下回らないようにする.

有限要素解析の要素数を $n$, 要素体積を $V_{e}$ とし, 離散化された形式で最適化問題の定式化を行うと次のように なる.

$$
\begin{array}{ll}
\min _{h^{(\alpha)}} & f=\boldsymbol{F}^{T} \boldsymbol{d} \\
\text { subject to: } & K \boldsymbol{d}=\boldsymbol{F} \\
& g=\frac{V_{e}}{l} \sum_{j}^{n}\left\{h_{j}^{(1)}+h_{j}^{(2)}+\sqrt{2}\left(h_{j}^{(3)}+h_{j}^{(4)}\right)\right\}-V_{\max } \leq 0 \\
& h_{\min } \leq h_{j}^{(\alpha)} \leq h_{\max } \quad \text { for } \quad \alpha=1,2,3,4 \quad j=1,2, \ldots, n
\end{array}
$$

続いて，ラグランジュ未定乗数法と随伴変数法を用いて，この制約付き最適化問題を無制約最適化問題に置き

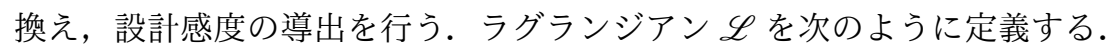

$$
\mathscr{L}\left(h^{(\alpha)}, \boldsymbol{p}, \boldsymbol{q}, \mu\right)=\boldsymbol{F}^{T} \boldsymbol{p}+\boldsymbol{q}^{T}(\boldsymbol{F}-K \boldsymbol{p})+\mu g
$$

ここで, $\boldsymbol{p}$ は状態変数， $\boldsymbol{q}$ 及び $\mu$ はラグランジュ乗数である. まず，ラグランジュ乗数 $\boldsymbol{q}$ について停留条件を考 えると,

$$
\frac{\partial \mathscr{L}}{\partial \boldsymbol{q}}=\boldsymbol{F}-K \boldsymbol{p}=0
$$

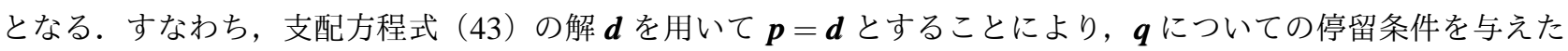
ことになる. 次に, 状態変数 $\boldsymbol{p}$ についての停留条件は

$$
\frac{\partial \mathscr{L}}{\partial \boldsymbol{p}}=\boldsymbol{F}^{T}-\boldsymbol{q}^{T} K=0
$$

となる. こちらも，支配方程式（43）の解 $\boldsymbol{d}$ を用いて $\boldsymbol{q}=\boldsymbol{d}$ とすることにより，pについての停留条件を与えた ことになる. 最後に, ラグランジアン $\mathscr{L}$ の設計変数 $h^{(\alpha)}(\alpha=1,2,3,4)$ にいての勾配に対して, $\boldsymbol{q}, \boldsymbol{p}$ の停留条 件を与えると, 設計感度を得られる. したがって, ラグランジアン $\mathscr{L}$ の設計変数 $h^{(\alpha)}$ に対する感度は次のように なる.

$$
\frac{\partial \mathscr{L}}{\partial h^{(\alpha)}}=-\boldsymbol{d}^{T} \frac{\partial K}{\partial h^{(\alpha)}} \boldsymbol{d}+\mu \frac{\partial g}{\partial h^{(\alpha)}}
$$




\section{5. 数 值 例}

本章では，提案手法を用いて剛性最大化問題の例題を解き，その妥当性について検証する.

図 5 で示すように, マクロスケールにおける設計領域 $\Omega$ は縦 $1.0 \mathrm{~m}$, 横 $3.0 \mathrm{~m}$ の長方形であり, 左端 $\Gamma_{\text {fixed }}(=$ $\left.\Gamma_{u}=\Gamma_{\phi}\right)$ にて変位とマイクロ回転を固定し, 下端右 $\Gamma_{t}$ に下向きの表面力のみを加える. 設計領域は $40 \times 120$ の四 辺形一次要素に分割する. このとき, 要素の一辺の長さは $0.025 \mathrm{~m}$ である. また, ヤング率 $E=3.0 \mathrm{GPa}$, ポアソ ン比 $v=0.30$ とする. 4 章の通り, 本数值例では設計变数の側面制約と体積の上限制約を課す. 設計変数につい ては, ユニットセルの一辺の長さ $l$ に対し, 最小值 $h_{\min }=l / 100$, 最大值 $h_{\max }=l / 20$ と規定する. ユニットセル 内で全て梁の幅がこの最大值 $h_{\max }=l / 20$ となる場合の正規化された密度 $\rho$ を $\rho_{\max }$ と表し, 体積の上限值 $V_{\max }$ に ついては，各点の密度が $\rho_{\max }$ である場合の体積を基準として，その $40 \%$ と設定する.

本数值例では, $l=0.01 \mathrm{~m}, 0.001 \mathrm{~m}$ のつの場合について最適化を適用した. なおこの格子構造に対し, 梁要素 によるモデル化とマイクロポーラ弾性体によるモデル化を用いて数值解析を行い, その精度について予備検証を 行った. その結果, この設計モデルの場合 $l=0.01 \mathrm{~m}$ 以下であれば, 両者の変位の相対誤差は $3 \%$ 未満になるこ とを確認した．またこの検証結果より，ユニットセルのサイズが小さいほど誤差がより小さくなることが分かっ た。これは, マイクロポーラ弾性体の弾性テンソルを導出する際に, 一次のテイラー展開を用いて隣り合う節点 間の梁のひずみエネルギーを導出するため, 節点間の距離が近い, つまり $l$ が小さい方がテイラー展開による近似 がより正確になるからであると考えられる.

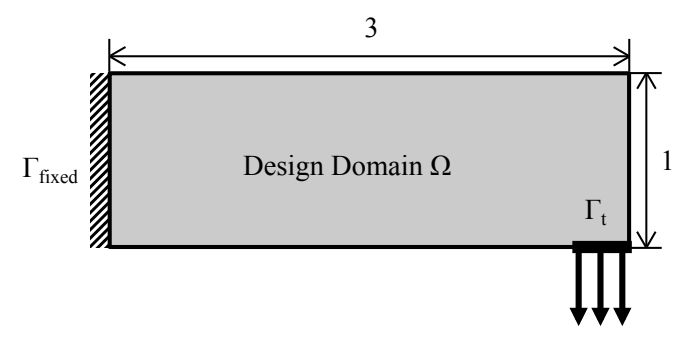

Fig. 5 Design domain settings and boundary conditions in macroscale.

まず $l=0.001 \mathrm{~m}$ とし最適化を行った結果を示す. 図 6 に, 得られた最適構造において設計変数である梁の幅 $h^{(\alpha)}(\alpha=1,2,3,4)$ の分布を示す. 図 7 に, 式（31）に示した正規化されたマクロ構造の密度 $\rho$ の分布と各点での ミクロ構造を示す. さらに, 最適構造における主応力及び主せん断応力の值とその方向を図 8 に示す. なお, 古典 弾性体の場合, 主せん断応力は絶対值が等しく正負が異なる二つの值をとり, この絶対值の最大值を最大せん断応 力と呼ぶが，マイクロポーラ弾性体については応力の非対称性より主せん断応力が異なる二つの值をとるので, こ こではこれらのうち大きい方の值を最大せん断応力と呼び，小さい方の值を最小せん断応力と呼ぶこととする.

図 6 及び図 8 より, 梁はせん断方向の変形よりも軸方向の変形に対して剛性が高いため, 限られた体積で剛性 を高めるために，主応力方向が軸方向となる梁の幅のみを太くしていると考えられる．この結果から，マクロ構 造の剛性を最大化するという目的に対し力学的に妥当な解が得られていることが分かる.

次に $l=0.01 \mathrm{~m}$ と設定して, 同様に最適化を行った結果を示す. 図 9 に, 得られた最適構造において設計变数 である梁の幅 $h^{(\alpha)}(\alpha=1,2,3,4)$ の分布を示す.

図 6, 9 より, ユニットセルのサイズの違いが設計変数の分布に違いをもたらすことが分かる. 図 6 と図 9 を比 較すると, 特に設計変数 $h^{(3)}, h^{(4)}$ の分布について, ユニットセルの一辺の長さ $l$ が大きいときの方が，より単純 な構造になっている.この理由について考察する. 図 10 にそれぞれの場合の密度 $\rho$ の分布とマイクロ回転 $\phi$ の 分布を示す. 図 10 内の破線で囲んだ部分などに見られるように, 梁の幅が変わる境目で局所的にマイクロ回転の 大きさが大きくなっていることがわかる，すなわち，破線部ではマイクロポーラ弾性体の曲率が大きいといえる. 式（24）から式（29）に示すように, 弾性テンソルのうち $K_{i 3 j 3}$ に相当する項のみが $l$ の乗のオーダーに依存す ることから, マイクロポーラ弾性体としてのひずみエネルギーについて, $l$ が大きくなるほど曲率のもたらす寄与 分が大きくなる．したがって，lが大きくなるほど梁の幅の変わる境目を減らすことによって曲率のもたらすひず 


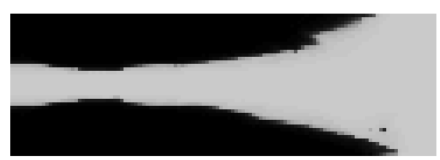

(a)

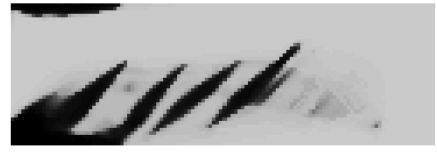

(c)

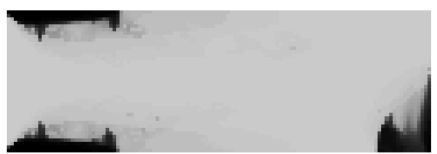

(b)

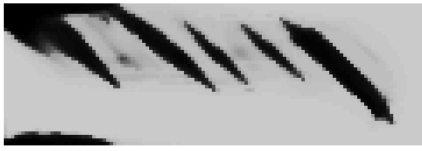

(d)

Fig. 6 Optimum distributions of the width of beams which are headed in each direction in unit cell of $l=0.001 \mathrm{~m}$ : (a) $h^{(1)}$, (b) $h^{(2)}$, (c) $h^{(3)}$ and (d) $h^{(4)}$.

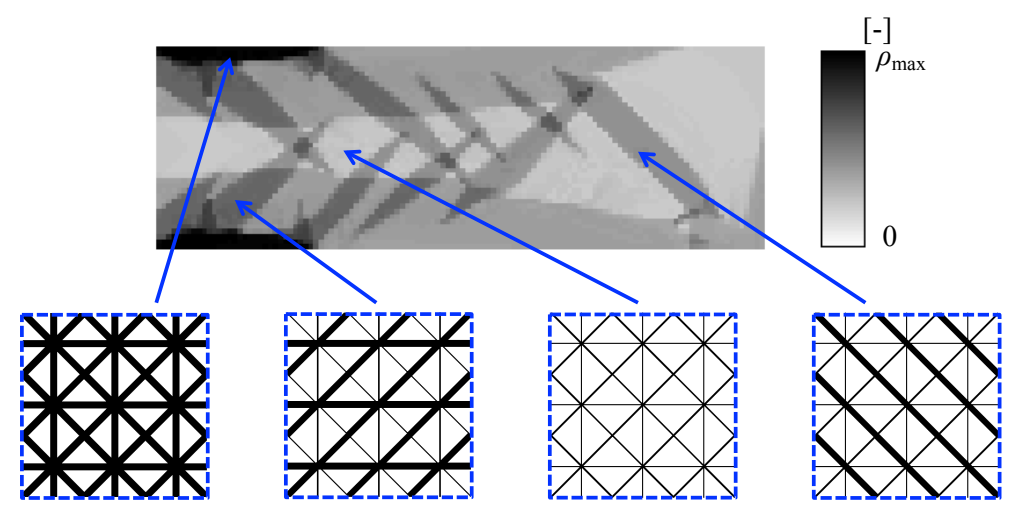

Fig. 7 Distribution of the normalized density $\rho$ and configurations of the microstructure at each point.

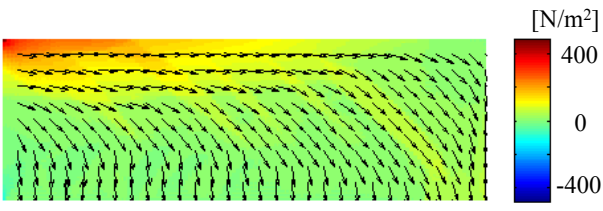

(a)

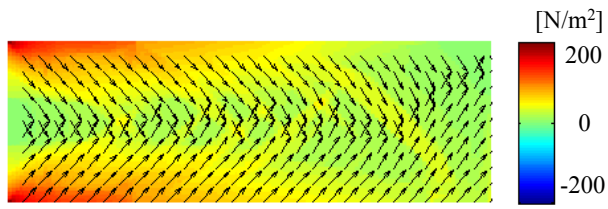

(c)

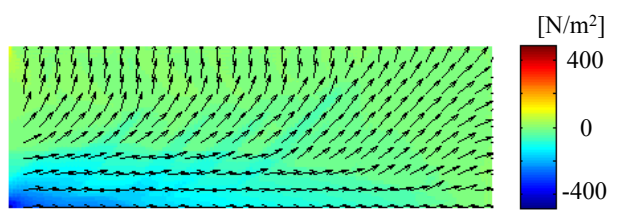

(b)

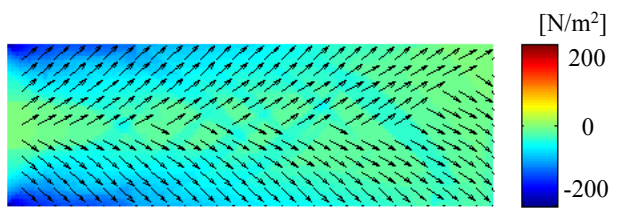

(d)

Fig. 8 Macroscopic distributions of (a) maximum principal stress, (b) minimum principal stress, (c) maximum shear stress and (d) minimum shear stress. Arrows show the direction of each principal stress.

みエネルギーを抑えていると考えられる. また, 力学的な観点から考えると, マイクロ回転が大きくなるという ことは，図 2 より節点の回転が大きくなるということである. 式 (18) より，梁が長い方が節点の回転がもたらす ひずみエネルギー分が大きいので，一本の梁が長い場合，つまりユニットセルのサイズ $l$ が大きい場合では，梁の 幅が変わる境目でマイクロ回転が大きくなるという現象をできるだけ抑制していると考えられる，以上より，ユ 


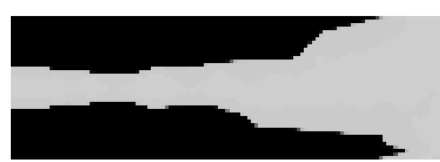

(a)

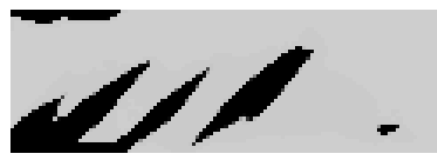

(c)

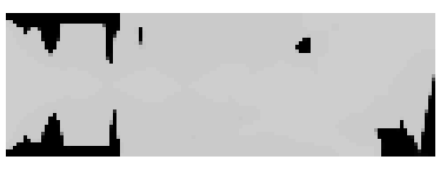

(b)

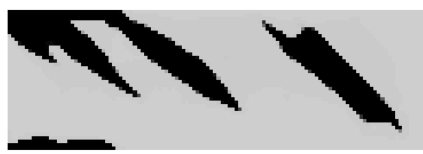

(d)

Fig. 9 Optimum distributions of the width of beams which are headed in each direction in unit cell of $l=0.01 \mathrm{~m}$ : (a) $h^{(1)}$, (b) $h^{(2)}$, (c) $h^{(3)}$ and (d) $h^{(4)}$.

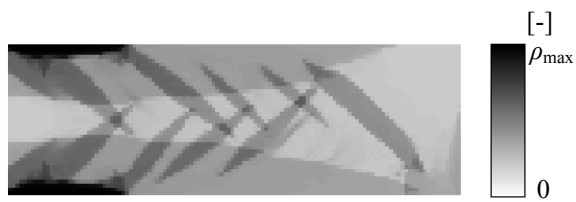

(a)

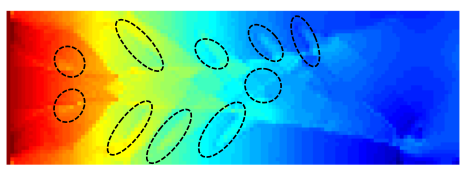

(c)

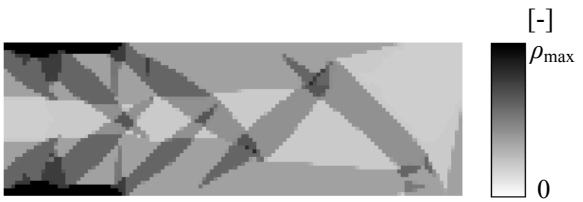

(b)

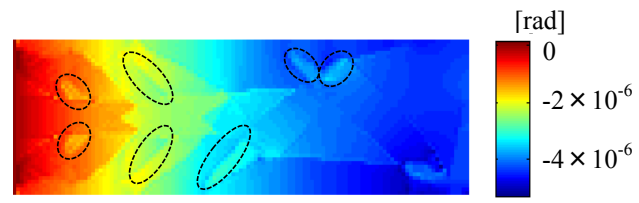

(d)

Fig. 10 Comparison of size effect: (a) normalized density $\rho$ for $l=0.001 \mathrm{~m}$, (b) normalized density $\rho$ for $l=0.01$ $\mathrm{m}$, (c) micro-rotation $\phi$ for $l=0.001 \mathrm{~m}$ and (d) micro-rotation $\phi$ for $l=0.01 \mathrm{~m}$.

ニットセルのサイズの変化に対しても力学的に妥当な結果が得られていることが分かった.

\section{6. 結言}

本研究では，梁要素で構成された格子構造に対して，マイクロポーラ弾性体としての連続体表現を利用し，各 方向に軸をとる梁の幅を設計変数として格子構造の最適設計を行う手法を提案した. 以下に本研究の成果をまと める.

1. ユニットセル内の梁の幅が異なる格子構造に対して, マイクロポーラ弾性体としてモデリングした場合の弾 性係数を導出した。

2. マクロ構造の剛性を最大化するような梁の幅の分布を求める最適化問題を定式化した。さらに，その最適化 アルゴリズムを構築し, 有限要素法による数值実装を行った。

3. 数值例において, 提案手法の有効性と妥当性を検証した. 得られた最適構造について, 主応力方向が軸力方向 となる梁の幅が大きくなっていたことから，力学的に妥当な解であることを確認した。また，ユニットセルの サイズが大きいほどより単純な構造が得られており，サイズの影響を考慮した解が得られることが分かった。

$$
\text { 文献 }
$$

Adachi, T., Tomita, Y. and Tanaka, M., Computational simulation of deformation behavior of 2D-lattice continuum, 
International Journal of Mechanical Sciences, Vol.40, No.9 (1998), pp.857-866.

Bažant, Z. P. and Christensen, M., Analogy between micropolar continuum and grid frameworks under initial stress, International Journal of Solids and Structures, Vol.8, No.3 (1972), pp.327-346.

Elsayed, M. S. and Pasini, D., Multiscale structural design of columns made of regular octet-truss lattice material, International Journal of Solids and Structures, Vol.47, No.14 (2010), pp.1764-1774.

Eringen, A. C., Linear theory of micropolar elasticity, Journal of Mathematics and Mechanics, Vol.15, No.6 (1966), pp.909-923.

Ju, J. and Summers, J. D., Compliant hexagonal periodic lattice structures having both high shear strength and high shear strain, Materials \& Design, Vol.32, No.2 (2011), pp.512-524.

Kumar, R. S. and McDowell, D. L., Generalized continuum modeling of 2-D periodic cellular solids, International Journal of Solids and Structures, Vol.41, No.26 (2004), pp.7399-7422.

Lantada, A. D. and Morgado, P. L., Rapid prototyping for biomedical engineering: current capabilities and challenges, Annual Review of Biomedical Engineering, Vol.14, No.4 (2012), pp.73-96.

西脇眞二, 西垣英一, 鶴見康昭, 小島芳生, 菊池昇, 梁要素を用いたトポロジー最適化（第 1 報, 静的な剛性の 最大化の場合），日本機械学会論文集 C 編, Vol.67, No.662 (2001), pp.3069-3077.

Noor, A. K. and Nemeth, M. P., Micropolar beam models for lattice grids with rigid joints, Computer Methods in Applied Mechanics and Engineering, Vol.21, No.2 (1980), pp.249-263.

Noor, A. K. and Nemeth, M. P., Analysis of spatial beamlike lattices with rigid joints, Computer Methods in Applied Mechanics and Engineering, Vol.24, No.1 (1980), pp.35-59.

Onck, P. R., Cosserat modeling of cellular solids, Comptes Rendus Mecanique, Vol.330, No.11 (2002), pp.717-722.

Svanberg, K., The method of moving asymptotes - a new method for structural optimization, International Journal for Numerical Methods in Engineering, Vol.24, No.2 (1987), pp.359-373.

Vasiliev, V. V. and Razin, A. F., Anisogrid composite lattice structures for spacecraft and aircraft applications, Composite Structures, Vol.76, No.1 (2006), pp.182-189.

Yan, J., Cheng, G., Liu, S. and Liu, L., Comparison of prediction on effective elastic property and shape optimization of truss material with periodic microstructure, International Journal of Mechanical Sciences, Vol.48, No.4 (2006), pp.400-413.

Yan, J., Cheng, G., Liu, L. and Liu, S., Concurrent material and structural optimization of hollow plate with truss-like material, Structural and Multidisciplinary Optimization, Vol.35, No.2 (2008), pp.153-163.

\section{References}

Adachi, T., Tomita, Y. and Tanaka, M., Computational simulation of deformation behavior of 2D-lattice continuum, International Journal of Mechanical Sciences, Vol.40, No.9 (1998), pp.857-866.

Bažant, Z. P. and Christensen, M., Analogy between micropolar continuum and grid frameworks under initial stress, International Journal of Solids and Structures, Vol.8, No.3 (1972), pp.327-346.

Elsayed, M. S. and Pasini, D., Multiscale structural design of columns made of regular octet-truss lattice material, International Journal of Solids and Structures, Vol.47, No.14 (2010), pp.1764-1774.

Eringen, A. C., Linear theory of micropolar elasticity, Journal of Mathematics and Mechanics, Vol.15, No.6 (1966), pp.909-923.

Ju, J. and Summers, J. D., Compliant hexagonal periodic lattice structures having both high shear strength and high shear strain, Materials \& Design, Vol.32, No.2 (2011), pp.512-524.

Kumar, R. S. and McDowell, D. L., Generalized continuum modeling of 2-D periodic cellular solids, International Journal of Solids and Structures, Vol.41, No.26 (2004), pp.7399-7422.

Lantada, A. D. and Morgado, P. L., Rapid prototyping for biomedical engineering: current capabilities and challenges, Annual Review of Biomedical Engineering, Vol.14, No.4 (2012), pp.73-96.

Nishiwaki, S., Nishigaki, H., Tsurumi, Y., Kojima, Y. and Kikuchi, N., Topology optimization using beam elements (1st report, Optimal Design in case of maximizing static stiffness), Transactions of the Japan Society of Mechanical 
Engineers, Series C, Vol.67, No.662 (2001), pp.3069-3077 (in Japanese).

Noor, A. K. and Nemeth, M. P., Micropolar beam models for lattice grids with rigid joints, Computer Methods in Applied Mechanics and Engineering, Vol.21, No.2 (1980), pp.249-263.

Noor, A. K. and Nemeth, M. P., Analysis of spatial beamlike lattices with rigid joints, Computer Methods in Applied Mechanics and Engineering, Vol.24, No.1 (1980), pp.35-59.

Onck, P. R., Cosserat modeling of cellular solids, Comptes Rendus Mecanique, Vol.330, No.11 (2002), pp.717-722.

Svanberg, K., The method of moving asymptotes - a new method for structural optimization, International Journal for Numerical Methods in Engineering, Vol.24, No.2 (1987), pp.359-373.

Vasiliev, V. V. and Razin, A. F., Anisogrid composite lattice structures for spacecraft and aircraft applications, Composite Structures, Vol.76, No.1 (2006), pp.182-189.

Yan, J., Cheng, G., Liu, S. and Liu, L., Comparison of prediction on effective elastic property and shape optimization of truss material with periodic microstructure, International Journal of Mechanical Sciences, Vol.48, No.4 (2006), pp.400-413.

Yan, J., Cheng, G., Liu, L. and Liu, S., Concurrent material and structural optimization of hollow plate with truss-like material, Structural and Multidisciplinary Optimization, Vol.35, No.2 (2008), pp.153-163. 